\title{
An Analysis On The Results Of Public Information Policy Implementation At West Java Government
}

\author{
Diah Fatma Sjoraida \\ Fakultas Ilmu Komunikasi, Universitas Padjadjaran \\ Jatinangor, Indonesia \\ diah.fatma@unpad.ac.id \\ Rully Khairul Anwar \\ Fakultas Ilmu Komunikasi, Universitas Padjadjaran \\ Jatinangor, Indonesia \\ rully.khairul@unpad.ac.id
}

\begin{abstract}
This article investigates the implementation of Law Number 14/2008 on Public Information Disclosure or in Bahasa Indonesia called Keterbukaan Informasi Publik (KIP) of West Java Provincial Government. This descriptive-qualitative study presented a discussion of the results in the implementation processes of the policy as mentioned above in West Java Province of Indonesia. With the theory of policy implementation, the data obtained shows that the results of the application of public information policy in the government of West Java had many deficiencies on its implementers, structures, planning, facilities and infrastructure, and others. Therefore, a significant improvement is needed in the implementation of the law in West Java. Nevertheless, the implementation of the Act had received a decent acknowledgment at the national level and among the local community.
\end{abstract}

Keywords- Policy Implementation; Public Information Transparency; West Java Provincial Government.

\section{INTRODUCTION}

The Indonesian Constitution has guaranteed the right of the citizens to communicate and have the freedom to access information. Based on Article 28f of the 2nd Amendment of Indonesian's Constitution of 1945, the government has issued Law No. 14 of 2008 on public information disclosure (from now on referred to as KIP Law) as the government's commitment to open the era of public disclosure in Indonesia. Besides, it also opens the basis for public engagement to know the process. It is done for the decision-making process concerning public's life and interest, and the process of implementing and evaluating the practice of governance at all levels from the central to the regional government.

The enactment of the KIP Law (Public Information Disclosure Act) mandates the government and other public organizations to open access to information for the society by building and developing information systems and documentation actively. Therefore, all information is accessible to the public widely, quickly and easily. Also, the government must fulfill the information requested by the public. The domain of information rights that can be publicly accessed, as guaranteed by the KIP Law, is the right for the transparency of public funds/resources management, the right to information managed by public organizations, and the right to information of the performance of officials in performing government functions.

To make the KIP Law works properly, every sector of government's bureaucracy, especially at the regional level, should have a Regional Information Management Officer (from now on referred to as Pejabat Pengelola Informasi dan Dokumentasi (PPID)) and establish a Regional Information Commission (KID). For the provincial government, the Information Commission established is the Provincial Information Commission (KID), while at the regency or city, it is called the Regency/Municipal Information Commission (KID).

The fact shows that implementation of public information disclosure regulation (KIP Law) in West Java led to conflicts due to various clashes of interest in the field. Related to the conflicts, the author is interested to know the real process of KIP Law implementation undergone by the Government of West Java Province, as well as to determine factors that support and impede the successful implementation of KIP Law in West Java. Thus, it is expected to provide a true portrayal and understanding of the conditions and problems related to the implementation of public information disclosure in West Java.

Regarding the information disclosure, West Java was rank $6^{\text {th }}$ at the national level in 2015's evaluation with the score of 72.994 out of 100 points. Aceh, East Java, East Kalimantan, West Nusa Tenggara, and Central Java are among the first to fifth rank, with the score of 94.111, 88.639, 81.188, 80.417, and 74.861 respectively.[1]

\section{RESEARCH METHOD}

To obtain the valid data and information, I use observation, interviews, and documentation as data collection techniques, about the object of research that includes themes, policies, and the implementation of information services at the government 
of West Java. Data collection is done through direct observation, in which the researcher took a role in certain situations and participated in some events. The activities that are observed directly in this research are the process of implementing the rules and providing information services to the public. It also observed several components such as human resources apparatus implementers, facilities, and infrastructure, program planning and activities, bureaucratic structure, the function of coordination between agencies and information services to the public. The research also uses three types of the interviews to support its qualitative approach, in line with Patton formulation, namely; informal conversation interviews, general interview, and standardized open interviews" with all informants.[2]

\section{RESULT AND DISCUSSION}

Based on the results of process analysis, some factors made the implementation of public information disclosure policy in West Java Provincial Government run ineffectively. Those factors are the mentality and culture of the institution; the unclarity of the structure and authority of officers; multiinterpretation of public information and supporting policies; the interpretation of freedom and belief of society; limited budget and supporting resources; and the inappropriate implementation of the service's pattern.

Work culture and mentality of the human resources in the implementation of information services to the public in West Java can be considered to be weak. Although socialization and technical guidance related to the implementation of KIP Law have been conducted several times, the officers were not able to implement it well. The weak mentality is seen from the public organizations that tend to be slow in the West Java Provincial Government, namely OPD-OPD, in updating the information that must be announced on the government's website named jabarprov.go.id. Besides that, it is also slow in responding the public demand for certain information of a closed-ended culture that concern about data accessed by the public may disclose state confidential information that should not be publicly accessible.

Also, the public information service is not rewarded as it should be in for their work performance (overtime). The public service information held by PPID is still regarded not as the main function yet as a side function, which is included in tupoksi (main task and function). This public information service affair is, though, really consuming time, energy and mind, as well as it requires special attention and concentration.

There is still a debate between the government, society and the regional information commission (KID) of West Java regarding information that can and cannot be publicly accessed. It is due to the absence of supporting policies, particularly on the mechanisms of information test implementation, the harm test consequential and the public interest test, which should be done to classify the information.

Another challenge is the public perception of the seriousness of West Java Provincial Government in realizing a government that holds the principle of transparency and accountability. Until now, the implementation of public information disclosure policy in West Java has not been able to change people's lousy perception of government performance and government's transparency intention. Poor public perception of the government (Liu in the National Association of Government Communicators, 2008) is one of eight challenges and opportunities that the government faces.

The budget in each OPD is not sufficient because the government does not specifically allocate budget for the implementation of this public information service affair. Budget limitation caused the West Java Provincial Government to rely solely on external socialization through the Provincial Government website but did not conduct socialization in the mass media, especially in the mainstream media. As a result, the dissemination of information to the public is not working properly.

Supporting resources and human resources in utilizing technology and information are also insufficient. From the field, it is known that the officers who serve the public information business need a more proper facility (both equipment and knowledge) so the public service can be done well.

The successful implementation of public information disclosure policy in West Java Province is very dependent on how the implementation process in achieving the objectives of the policy mandate. Implementation of decentralization pattern though not wrong, is less efficient in the application of public information service. With this model, public information service standards in each OPD are not the same, and it is challenging to synergize the information services due to the weak communication and coordination within the West Java Provincial Government (i.e., between OPDs). Therefore, efforts to implement the centralization pattern are expected to improve the quality of information service and community satisfaction.

Implementation of decentralization patterns here is to provide a fast, precise and easy service. However, the application of this pattern is not accompanied by a complete organization that implements it, which precisely handles the affairs of public information services, so the services become obstructed. Similarly, requests for information are proceeded directly by individual OPDs. However, decentralization will cause non-uniform categorization. So, this study suggests that there is a need for an immediate implementation of the centralization pattern by establishing the main PPID structure (Provincial PPID), the secretary of the PPID, and the assistant PPID is very high. Consequently, the public information service is more systematically coordinated and synergic between the provincial government and the OPDs as well as government of every regency and city in West Java Province. Therefore, it is necessary to immediately establish the main PPID (or Provincial PPID) which is responsible for the overall public information service and can monitor government information accessed by the society.

The formation of the ad hoc committee needs to be supported by the governor's regulation that regulates the mechanism of management and public information services. It is required as a guideline for all implementers and OPD in providing the best services to the applicant of information, including the provision of SOP so the selection and 
monitoring of public information services can be appropriately implemented.

Also, many public information requests have not been adequately managed yet by PPID in each OPD. The weakness in public information services is due to the task of PPID is only handled by a Secretary of the OPD and not supported by other supporting organizations such as functional officials. Whereas according to Article 13 of the Law of KIP states that in realizing a fast and precise public information service PPID should be assisted by the functional officials. One of them must have a public relations function in each OPD so it can accurately serve every request for information and documentation desired by the public.

At the provincial level, KID had not yet fully implemented the authority in providing policy support for the West Java Provincial Government in the form of general policy and technical guidance on the implementation of public information disclosure, as mandated by the KIP Law. According to Riant Nugroho, the implementation of a policy that goes accordingly with this principle is a way for a policy to achieve its goals.[3]

The situation of mutual responsibility is indeed happening in the implementation of KIP Law in West Java. For example, the actions performed by Diskominfo showed that if anyone requests information outside the controlled information, Diskominfo will forward the request for information to the intended OPD's e-mail link. The problem in each OPD is that they usually do not quickly open the email and know the progress of the request for information. Therefore, OPD seemed to be slow in responding the request for public information services.

According to information obtained during the interviews with West Java Diskominfo, the availability of information about West Java and West Java Provincial Government programs as requested by the information applicant should be the task and function of PPID in West Java Provincial Government and West Java Diskominfo. However, PPID Diskominfo in West Java suffers limited budget so that the fulfillment of people's right to obtain information disclosure has not been maximized. In receiving information, the society's effort is still limited to accessing the websites and desk services (if the request for information submitted by the public) in West Java Diskominfo office. In fact, the formation of PPID is based on the availability of information that can be accounted, which must be supported by a complete, accurate, and factual documentation. Public information disclosure is a means of optimizing public participation and supervision in the governance process. (Informant 1, March 2016)

In the implementation of public information service, West Java Provincial Government also requires to prepare a standard operating procedure (SOP) to ensure service certainty (type, time and standard cost of service), so public information service can be implemented systematically. However, until now, SOP about public information service in each OPD in West Java Provincial Government is not yet available.

With the enactment of this policy of public information disclosure, the government does not seem to be more open, but it seems to cover up certain information and becoming very bureaucratic on the requests that are submitted by the public. The reason for the 'fear' as mentioned above is a form of mental incompetence of the apparatus and officials towards the effort to change the paradigm of good governance that highly upholds democracy, public participation, and transparency.

Awareness of West Java Provincial Government apparatus to change the mindset of closure into transparency mindset results in a commitment to realize and implement public information disclosure policy either by Provincial Government or Regency and City Government in all area of West Java. Public information disclosure is like a lubricant that will accelerate changes in realizing a good governance that must be run by the bureaucracy. The disclosure of information is an essential and strategic instance in realizing the bureaucracy reform. Significant changes following the presence of the Public Information Disclosure Act become new challenges for government public agencies. Therefore, the public should also be proactive in asking the government to fulfill the promise to implement the KIP Law. Only by this way, the ideals of the emergence of a critical society will be realized, and the public can feel the benefits of KIP Law for an increasingly democratic life.

\section{CONCLUSION}

Based on the results and discussion of research, I formulate some conclusions as follows: 1) implementers (PPID) run by the Secretary of the OPD has not fully supported by supporting organizations. According to KIP Law, the implementation of PPID task needs to be assisted by officials with operative positions who specifically handle the affairs of PPID and services public information. It intends to minimize the burden of PPID in implementing the tasks and functions, 2) the implementation of KIP Law with the pattern of decentralization has weakened the functioning of the implementing organization. The execution of PPID duties in each OPD is run independently. It is not integrated and coordinated regarding the technical implementation of KIP Law in all OPD. 3) Also, the Provincial Information Commission (KID) has not yet fully applied its authority in providing policy support in the form of general policy, technical guidelines for the implementation of public information disclosure, as mandated by KIP Law, 4) public information request services do not fully meet the expectations of the society.

Public organizations within the West Java Provincial Government seem to be obscuring the information, responding slowly, and the information provided is inappropriate, and 5) West Java Provincial Government has not yet made a list of information services that are accessible to the public. The absence of such information service list happens because OPDs has not yet prepared information classification of which information should be available at any time, information that is promptly announced, periodic, as well as excluded information, 6) the carrying capacity of the policy at the local level is still generally low. Lack of policies and weak implementing regulations at the local level make the executing 
bureaucrats feel confused. Policy and regulation of implementation guidelines and technical guidance are still weak, such as lack of public information service in each OPD, list of information services, and code of ethics governing KID behavior.

7) The government lacks Standard Operating Procedures (SOP) in public information service in each of the OPDs, so the public cannot get a guarantee about the timeline and process that they should go through. 8) The increasingly high public information disputes are caused by such things as the slow public service request, the inappropriate information given to the public, and the inability to provide the requested information.

9) Since the enactment of the KIP Law, the public organization felt more concerned which caused misunderstanding in providing public information. For example, under certain circumstances, a public organization will violate the law if it gives the information to the public. On the other hand, if the information is not provided, the public organization may face a lawsuit which can result in the imposition of both criminal and civil sanctions. 10) Lastly, following thes implementation of the KIP Law, the ideals of the emergence of a critical society will be realized and hopefully the society will feel the benefits of KIP Law for an increasingly democratic life.

\section{Acknowledgment}

The article is a part of our dissertation project.

\section{References}

[1] Arie C. Meliala, "Pemprov Jabar Peringkat VI Keterbukaan Informasi Publik," Pikiran Rakyat, 2015.

[2] M. Q. Patton, Qualitative Research and Evaluation Methods, 3rd ed. London: Sage Publications, 1990.

[3] R. N. Dwijowijoto, Kebijakan Publik Formulasi, Implementasi dan Evaluasi. Jakarta: PT Elex Media Komputindo. 